\title{
Salt intake and its sources in children, adolescents and adults in the Islamic Republic of Iran
}

Noushin Mohammadifard, ${ }^{1}$ Atena Mahdavi, ${ }^{2}$ Alireza Khosravi, ${ }^{3}$ Ahmad Esmaillzadeh, ${ }^{4}$ Awat Feizi ${ }^{5}$ and Nizal Sarrafzadegan ${ }^{6,7}$

${ }^{1}$ Pediatric Cardiovascular Research Center, Cardiovascular Research Institute, Isfahan University of Medical Sciences, Isfahan, Islamic Republic of Iran. ${ }^{2}$ Interventional Cardiology Research Center, Cardiovascular Research Institute, Isfahan University of Medical Sciences, Isfahan, Islamic Republic of Iran. ${ }^{3}$ Hypertension Research Center, Cardiovascular Research Institute, Isfahan University of Medical Sciences, Isfahan, Islamic Republic of Iran. ${ }^{4}$ Department of Community Nutrition, School of Nutritional Sciences and Dietetics, Tehran University of Medical Sciences, Tehran, Islamic Republic of . ${ }^{5}$ Epidemiology and Biostatistics Department, School of Health, Cardiac Rehabilitation Research Center, Cardiovascular Research Institute, Isfahan University of Medical Sciences, Isfahan, Islamic Republic of Iran. ${ }^{6}$ Isfahan Cardiovascular Research Center, Cardiovascular Research Institute, Isfahan University of Medical Sciences, Isfahan, Islamic Republic of Iran (Correspondence to: N. Sarrafzadegan: nsarrafzadegan@gmail.com). 7School of Population and Public Health, Faculty of Medicine, University of British Columbia, Vancouver, Canada.

\begin{abstract}
Background: There is little evidence about salt intake and its food sources in the Iranian population, especially in children and adolescents.

Aims: To investigate salt intake and dietary sources in Isfahan, Islamic Republic of Iran.

Methods: This was a cross-sectional survey conducted in 2014-2015. We randomly selected 1384 adults (50.3\% female, $49.7 \%$ male) aged $>18$ years [mean 37.9 (10.6) years], and 786 children and adolescents (50.9\% male, $49.1 \%$ female) aged 6-18 years [mean 12.5 (3.4) years]. All participants underwent a dietary assessment for salt intake, using a validated food frequency questionnaire.

Results: The total salt intake was 10.9 (3.4) g/day in adults and 10.3 (2.9) g/day in children and adolescents. Added salt was the primary source of salt intake, followed by bread and cheese in both groups. Salt intake was related significantly to being younger, male, a smoker, less educated and physically active in the adult group. In children and adolescents, it was significantly associated with increasing age, male sex, low physical activity and parents' education level (all $P<0.05)$.

Conclusions: Salt intake in Isfahan was more than twice that recommended by the World Health Organization. The main source of sodium was added salt, followed bread and cheese. Future national studies are warranted to assess the dietary salt intake and its main sources in different provinces in the Islamic Republic of Iran.

Keywords: nutrition surveys, sodium chloride, dietary source, dietary sodium, Islamic Republic of Iran

Citation: Mohammadifard N; Mahdavi A; Khosravi A; Es maillzadeh A; Feizi A; Saarfzadegan N, et al. Salt intake and its sources in children, adolescents and adults in Isfahan, Islamic Republic of Iran. East Mediterr Health J. 2021;27(3):279-286 https://doi.org/10.26719/2021.27.3.279

Received: 27/07/19; accepted: 01/04/20

Copyright (c) World Health Organization (WHO) 2021. Open Access. Some rights reserved. This work is available under the CC BY-NC-SA 3.o IGO license (https://creativecommons.org/licenses/by-nc-sa/3.o/igo).
\end{abstract}

\section{Introduction}

High salt intake can contribute to hypertension, cardiovascular disease (CVD), stroke, gastric cancer, osteoporosis and renal disease (1). About 1.65 million annual deaths in the Islamic Republic of Iran are attributed to cardiovascular events, among which, 7034 deaths were due to salt intake $>5 \mathrm{~g} /$ day in 2010 (2).

Salt intake reduction is the most efficient approach for reducing the global burden of hypertension and CVD (3). Thus, the World Health Organization (WHO) recommends that Member States reduce salt intake in their populations by $30 \%$ by 2025 (4). It is imperative to assess salt intake and its major sources in various nations (5). Mean daily salt intake based on 24-hour urinary sodium excretion was $10.2 \mathrm{~g} /$ day in the Iranian population, and it was higher in men than women in 2013 (6). The method of 24-hour urine collection is the gold standard for evaluation of salt consumption. However, this method tends to underestimate salt intake (7), and it cannot determine the food sources.
The major source of dietary sodium is processed food in adults who live in western countries (8), while snacks have the same role in adolescents (9). Traditional Japanese foods, including soy sauce and dried fish products provide high amounts of salt in the Japanese population (10). In China, added salt, soy sauce, monosodium glutamate and processed foods are the major sources of sodium intake (11). To the best of our knowledge, there is no evidence about salt intake and its sources in any Iranian community according to age group, especially children and adolescents. Therefore, in the current study, we aimed to assess the sodium and salt intake and contribution of food to salt intake by a validated food frequency questionnaire (FFQ) in the city of Isfahan, Islamic Republic of Iran.

\section{Methods}

\section{Study design and participants}

This cross-sectional study was conducted among 2170 healthy participants, including 1384 adults aged $>18$ 
years, and 786 children and adolescents aged 6-18 years. The study was performed in 2014-2015 in Isfahan, the second biggest city in the Islamic Republic of Iran. Isfahan has 47 urban health centres. We selected an initial 18 clusters using a multistage cluster sampling method. Households were chosen by systematic random sampling based on the distribution of age and sex groups in the community, the proportion of population covered by the health centres, and the records in the centres. Then, 1 available adult from each household was recruited to complete our sample size in each age category. The inclusion criteria for adults were: age > 18 years; no history of chronic disease like CVD, diabetes mellitus, hypertension, thyroid disease, renal failure and liver disease; not being on a specific diet during the last year; nonpregnant or non-breastfeeding women; and not taking contraceptive drugs and dietary supplements. Individuals with incomplete data collection were excluded, as described previously (12). We recruited 1 or 2 children and adolescents ( 1 boy and/ or 1 girl) aged 6-18 years in each selected household, if possible. The response rate was $94 \%$. We called the participants and asked about missing questions. If they did not respond again, we excluded them from the study. The study was approved by the Isfahan Cardiovascular Research Institute (ICRI). Written informed consent was obtained from all participants.

\section{Data collection}

Trained health professionals carried out detailed interviews to obtain the required information, including socioeconomic and demographic characteristics. We assessed physical activity, using the International Physical Activity Questionnaire (13), and data collected were reported as metabolic equivalents of task (METs) minutes per week. METs thresholds as an indicator of physical activity intensity were measured continuously by calculating for walking, moderate-intensity activities, and vigorous-intensity activities. The intensity thresholds identified were 3.3 METs for walking, 4.9 for moderate physical activity and 6.8 for vigorous physical activity. A combined total physical activity was calculated as the sum of walking and moderate and vigorous METs.

\section{Anthropometric measurements}

Upon arrival in the ICRI, trained health professionals measured the participants' standing height to the nearest $0.5 \mathrm{~cm}$. Body weight was measured to the nearest $0.5 \mathrm{~kg}$, using a digital scale with the participants wearing light clothes and no shoes. Waist circumference and hip circumference were measured to the nearest $0.5 \mathrm{~cm}$ with nonstretchable measuring tape. Body mass index (BMI) was calculated by dividing weight $(\mathrm{kg})$ by height per metre squared $\left(\mathrm{m}^{2}\right)(14)$.

\section{Dietary assessment}

Dietary behaviour was assessed by a validated 136-item semiquantitative FFQ (15). This FFQ was developed to determine sodium intake and the contribution of food to intake. All participants were requested to respond about their usual frequency of food item's consumption (average over the past year). Response categories ranged from never or rarely (<1/month), 1-3/month, 1/week, 2-4/ week, 5 or $6 /$ week, 1/day, 2 or 3/day, 4 or $5 /$ day and $\geq 6 /$ day. We calculated sodium intake, using the Iranian Food Consumption Program, and based on the Iranian Food Composition Table $(16,17)$. Food groups included dairy products (except for cheese), cheese, meats, processed meat and other meats (eggs, poultry, fish and red meat), vegetables, salty vegetables, fruits, grains (including breads and other grains), legumes, fast foods, canned foods, nuts and seeds, sweets, industrial beverages, fast foods, fat and oils. We estimated discretionary salt consumption through 4 questions, including the weight of the salt package that they usually use, how often and for how long the salt package is consumed, number of family members, and age of family members, as described previously (12). The percentage of sodium intake from each food group was calculated by dividing the amount of sodium intake from each group by total sodium intake and then multiplying by 100 .

\section{Statistical analysis}

The mean (standard deviation) and $\mathrm{n}(\%)$ were used to describe continuous and categorical variables, respectively. We used the weight of sodium $(23 \mathrm{~g} / \mathrm{mol})$ equivalent to 2.5 -fold of sodium chloride $(58.5 \mathrm{~g} / \mathrm{mol})$ to convert sodium intake to salt intake. The $\chi^{2}$ and Student's $t$ tests were used to compare the baseline characteristics. The percentage of food contribution in sodium intake was not normally distributed, thus the Mann-Whitney $U$ test was utilized. We utilized linear regression to examine the association of salt intake with age (years), sex (female/ male), education (years of education), current smoking (yes/no), physical activity (METs min/week), BMI (kg/ $\mathrm{m}^{2}$ ) and waist circumference $(\mathrm{cm})$. Statistical analyses were performed using SPSS for Windows 18.0 (SPSS, Chicago, IL, USA). The significance level was set at $P<0.05$.

\section{Results}

This study included 2170 participants (1384 adults and 786 children and adolescents; Table 1). In the adults, the mean age was 37.9 (10.6) years and $49.7 \%$ were men, while among children and adolescents, the mean age was 12.5 (3.4) years and $50.9 \%$ were boys.

The salt intake was 10.9 (3.4) g/day in adults and 10.3 (2.9) g/day in children and adolescents (Table 2). Salt intake was significantly higher in men and boys $(\mathrm{P}<0.001)$.

Salt sources like added salt, cheese and salty vegetables were significantly higher in females than males (all $\mathrm{P}<\mathrm{0.01}$ ) (Table 3). However, bread, fast food, sweets, processed meat and canned food made a significantly higher contribution to salt intake in men than women (all $P<0.001$ ). Added salt, cheese, and salty vegetables provided a significantly higher salt intake in girls than boys (all $P<0.01$ ), and bread, fast food, processed meat and junk food contributed more to the salt intake in boys than girls (all $P<0.05)$. 


\begin{tabular}{|c|c|c|c|c|c|c|}
\hline \multirow[t]{2}{*}{ Characteristics } & $\begin{array}{l}\text { Female } \\
n=696\end{array}$ & $\begin{array}{c}\text { Male } \\
n=688\end{array}$ & $\begin{array}{c}\text { Total } \\
n=1384\end{array}$ & $\begin{array}{c}\text { Girls } \\
n=386\end{array}$ & $\begin{array}{c}\text { Boys } \\
n=400\end{array}$ & $\begin{array}{c}\text { Total } \\
n=786\end{array}$ \\
\hline & \multicolumn{6}{|c|}{ Mean (SD) } \\
\hline Age (yr) & $37.6(9.8)$ & $38.2(11.4)$ & $37.9(10.6)$ & $12.4(3.4)$ & $12.5(3.3)$ & $12.5(3.4)$ \\
\hline Education (yr) & $10.5(3.9)$ & $11.3(3.6)$ & $10.9(3.8)$ & - & - & - \\
\hline Paternal education (yr) & - & - & - & $11.4(4.3)$ & $11.7(4.2)$ & $11.6(3.9)$ \\
\hline Maternal education (yr) & - & - & - & $10.8(4)$ & $10.6(4.1)$ & $10.7(3.7)$ \\
\hline $\begin{array}{l}\text { Physical activity (METs } \\
\text { min/wk) }\end{array}$ & $448.3(226.9)$ & $512.6(244.1)$ & $481.1(234.4)$ & $524.8(203.6)$ & $596.2(247.5)$ & $569.4(222.6)$ \\
\hline BMI $\left(\mathrm{kg} / \mathrm{m}^{2}\right)$ & $27.3(5)$ & $26.1(4.1)$ & $26.7(5.2)$ & $20.6(4.8)$ & $21.0(5.3)$ & $20.8(5.1)$ \\
\hline \multirow[t]{2}{*}{$\mathrm{WC}(\mathrm{cm})$} & $89.3(12.1)$ & $93(11.2)$ & $91.1(11.7)$ & $71.6(12.1)$ & $74.8(14.6)$ & $73.3(13.5)$ \\
\hline & \multicolumn{6}{|c|}{ Frequency n (\%) } \\
\hline \multicolumn{7}{|l|}{ Marital status, $\mathbf{n}(\%)$} \\
\hline Single & $82(11.8)$ & $156(22.7)$ & $238(17.2)$ & $383(99.2)$ & $393(98.2)$ & $776(98.7)$ \\
\hline Married & $591(84.9)$ & $518(75 \cdot 3)$ & $1109(80.1)$ & $3(0.8)$ & $7(1.8)$ & $10(1.3)$ \\
\hline Spouse (dead/divorced) & $23(3.3)$ & $14(2)$ & $37(2.6)$ & - & - & - \\
\hline Smokers, $n(\%)$ & $4(0.6)$ & $117(17)$ & $121(8.7)$ & $1(0.3)$ & $7(1.7)$ & $8(1)$ \\
\hline
\end{tabular}

The added salt, bread, cheese and salty vegetables significantly contributed to the salt intake in adults versus children and adolescents (all $P<0.05$ ), and fast foods, sweets, processed meat, junk food, nuts and seeds provided higher salt intake in children and adolescents than in adults (all $P<0.05$ ) (Table 4).

There was a significant negative correlation between salt intake and age, education, and total physical activity, and a significant positive correlation with male sex and smoking in the adult group (Table 5). In the children and adolescent group, age and male sex had a significant positive correlation, and parents' education level, and total physical activity had a significant negative correlation with salt intake (all $P<0.05$ ).

\section{Discussion}

In the current study, we assessed sodium and salt intakes using the validated FFQ in Isfahan, Islamic Republic of Iran. Sodium and salt intake were about twice as high in adults and the children and adolescent groups than the WHO recommended level. Total salt intake was about $1 \mathrm{~g}$ higher in men and boys than in women and girls. Added salt, bread and cheese were the three highest sources of sodium intake and provided about $70 \%$ of sodium in both groups.
Similar to our study, Mirzaei et al. reported higher salt intake in men than women in the Islamic Republic of Iran (18). Salt intake was higher than the WHO-recommended level and in western countries such as Germany and Belgium, and South Africa (19-21). Using three 24-hour dietary recalls, the National Health and Nutrition Study indicated that mean sodium intake in American adults based on age, sex and race ranged from 2.9 to $3.9 \mathrm{~g} /$ day, and was higher than the recommended level. Meat and cereal products were the two main sources of salt intake in all groups in the United States of America (USA) (5). The level of sodium intake in East Asian countries was generally more than twice the WHO-recommended level, and more than in western countries. This might have been due to high salt content of bread, meat products, soups, cheese and processed foods (22). In agreement with our findings, the salt intake was higher than the WHO-recommended level, and the main source of salt intake was added salt in the Asian countries $(23,24)$. In some European countries such as Austria, the main sources of salt intake were cereals, meat and dairy products (25). Similarly, bread made a major contribution to the salt intake in different countries including USA, many European countries and Australia (26-28).

Salt intake of adolescents in some countries such as the USA, Europe and Oceania was far above the recommended level and similar to our study. The main

\begin{tabular}{|c|c|c|c|c|c|c|c|c|}
\hline Salt intake & $\begin{array}{c}\text { Total } \\
\text { Mean (SD) }\end{array}$ & $\begin{array}{c}\text { Women } \\
\text { Mean (SD) }\end{array}$ & $\begin{array}{c}\text { Men } \\
\text { Mean (SD) }\end{array}$ & $\mathbf{P}^{*}$ & $\begin{array}{c}\text { Total } \\
\text { Mean (SD) }\end{array}$ & $\begin{array}{c}\text { Girls } \\
\text { Mean (SD) }\end{array}$ & $\begin{array}{c}\text { Boys } \\
\text { Mean (SD) }\end{array}$ & $P^{*}$ \\
\hline Added salt (g/d) & $5.1(2.7)$ & $5.1(2.8)$ & $5.2(2.7)$ & 0.57 & $4.5(2.2)$ & $4.4(2.2)$ & $4.5(2.3)$ & 0.456 \\
\hline Total salt (g/d) & $10.9(3.4)$ & $10.4(3.3)$ & $11.5(2.7)$ & $<0.001$ & $10.3(2.9)$ & $9.9(3.1)$ & $10.6(2.8)$ & $<0.001$ \\
\hline Total sodium (g/d) & $4.3(1.4)$ & $4.1(1.3)$ & $4.5(1.4)$ & $<0.001$ & $4.2(1.2)$ & $3.9(1.3)$ & $4.5(1.1)$ & $<0.001$ \\
\hline
\end{tabular}




\begin{tabular}{|c|c|c|c|c|c|c|}
\hline Food groups (\%) & $\begin{array}{c}\text { Women } \\
\text { Mean (SD) }\end{array}$ & $\begin{array}{c}\text { Men } \\
\text { mean (SD) }\end{array}$ & $P^{*}$ & $\begin{array}{c}\text { Girls } \\
\text { mean (SD) }\end{array}$ & $\begin{array}{c}\text { Boys } \\
\text { mean (SD) }\end{array}$ & $P^{*}$ \\
\hline Added salt & $48.7(14.2)$ & $45.3(14.2)$ & $<0.001$ & $44.7(13.2)$ & $42.5(12.2)$ & $<0.001$ \\
\hline Bread & $16.4(8)$ & $17.8(7.4)$ & $<0.001$ & $16(8.1)$ & $17.1(7.8)$ & $<0.001$ \\
\hline Cheese & $8.9(6.2)$ & $8.1(5.6)$ & 0.004 & $8.4(4.9)$ & $7.9(5.0)$ & 0.028 \\
\hline Dairy & $5.7(4.3)$ & $6(5.6)$ & 0.063 & $5.5(4.9)$ & $5.6(4.0)$ & 0.336 \\
\hline Salty vegetables & $6.3(5.3)$ & $4.2(3.4)$ & $<0.001$ & $5.1(5)$ & $3.7(4.8)$ & $<0.001$ \\
\hline Meat & $1.1(0.9)$ & $1.3(1.2)$ & 0.185 & $1.4(1.1)$ & $1.6(1.2)$ & 0.324 \\
\hline Fast food & $1.8(2.7)$ & $3.1(3.7)$ & $<0.001$ & $2.5(3.4)$ & $3.4(4.5)$ & $<0.001$ \\
\hline Sweets & $1.4(2.1)$ & $2.5(2.7)$ & $<0.001$ & $2.8(2.5)$ & $3.1(2.6)$ & 0.172 \\
\hline Processed meats & $3.6(2.7)$ & $4.4(3.2)$ & $<0.001$ & $5.9(4)$ & $6.7(4.5)$ & 0.002 \\
\hline Other vegetables & $1.3(1.2)$ & $1.1(0.97)$ & 0.126 & $1.3(1.1)$ & $0.9(1)$ & 0.154 \\
\hline Junk food & $1.9(2.1)$ & $2.1(2.3)$ & 0.142 & $2.2(1.9)$ & $3.3(2.1)$ & $<0.001$ \\
\hline Sauces & $0.6(0.7)$ & $0.8(0.9)$ & 0.173 & $0.8(0.9)$ & $0.9(1.1)$ & 0.332 \\
\hline Canned food & $0.8(0.9)$ & $1.5(1.2)$ & $<0.001$ & $1.0(1.2)$ & $1.3(1.5)$ & 0.194 \\
\hline Nuts and seeds & $0.6(0.8)$ & $0.5(0.7)$ & 0.253 & $0.8(1.1)$ & $1.1(1.3)$ & 0.212 \\
\hline Other cereals & $0.3(0.2)$ & $0.2(0.1)$ & 0.247 & $0.2(0.2)$ & $0.2(0.1)$ & 0.823 \\
\hline Fruits & $0.5(0.6)$ & $0.4(0.4)$ & 0.259 & $0.3(0.3)$ & $0.3(0.3)$ & 0.839 \\
\hline Legumes & $0.05(0.05)$ & $0.1(0.09)$ & 0.471 & $0.05(0.03)$ & $0.04(0.03)$ & 0.473 \\
\hline Fat and oils & $0.3(0.5)$ & $0.5(0.4)$ & 0.145 & $0.8(0.9)$ & $0.6(0.8)$ & 0.209 \\
\hline
\end{tabular}

source of salt intake was processed food, including industrial breads, which accounted for $15 \%$ of intake (29). Moreover, about $80 \%$ of adolescents in low- and middleincome countries frequently consumed salty snacks (30). However, inconsistent with our study, the Mis study of Slovenian adolescents showed that salt intake was higher in girls than boys (31). The salt intake was similar to the global level of salt intake. Hence, reducing salt intake is a health priority, particularly among younger age groups in our society and worldwide.

Since the main source of energy intake is derived from traditional bread consumption in the Iranian population, bread provided the highest salt intake after added salt. Moreover, unlike many parts of the world, bread and cheese are the most common form of breakfast in the Iranian population. Therefore, unlike western countries, processed food was not a major source of salt in our society. About $2 \%$ of salt is added to the flour as agreed and for consolidation of gluten compounds, which can be substituted with potassium and magnesium for fermentation of dough. However, Charlton et al. believe that 33\% reduction in salt in bread should not change its taste (32). Decreasing salt content in bread could play a major role in salt reduction in our population. However, it needs some intersectoral collaboration and advocacy with legislators, policy-makers and other stakeholders (3).

Since Iranian women and girls are more likely to eat homemade food than men are, the contribution of added salt, cheese and salty vegetables was higher in women and girls. However, fast food, processed meat and canned food provided more salt intake in men and boys, and junk food in boys, compared to women and girls. For the same reason as for added salt, bread, cheese and salty vegetables made a greater contribution to salt intake in adults, and fast foods, sweets processed meat, junk food, nuts and seeds contributed more for children and adolescents.

\begin{tabular}{|c|c|c|c|}
\hline \multicolumn{4}{|c|}{$\begin{array}{l}\text { Table } 4 \text { Food contribution in salt intake based on age group: } \\
\text { Isfahan Salt Study }\end{array}$} \\
\hline \multirow[t]{2}{*}{ Food item } & Adults & $\begin{array}{l}\text { Children and } \\
\text { adolescents }\end{array}$ & $P^{*}$ \\
\hline & Mean (SD) & Mean (SD) & \\
\hline Added salt & $47.1(14.2)$ & $43.6(12.7)$ & $<0.001$ \\
\hline Bread & $17.2(7.7)$ & $16.7(8.0)$ & 0.013 \\
\hline Cheese & $8.6(5.9)$ & $8.1(4.9)$ & 0.012 \\
\hline Dairy & $5.8(3.8)$ & $5.6(4.3)$ & 0.052 \\
\hline Salty vegetables & $5.3(4.6)$ & $4.3(4.6)$ & $<0.001$ \\
\hline Meat & $1.2(1)$ & $1.5(1.2)$ & 0.064 \\
\hline Fast foods & $2.4(1.8)$ & $3.0(2.6)$ & 0.008 \\
\hline Sweets & $1.9(1.7)$ & $3.0(2.2)$ & $<0.001$ \\
\hline Processed meat & $4.1(3.0)$ & $6.4(4.1)$ & $<0.001$ \\
\hline Other vegetable & $1.2(1.1)$ & $1.0(1.2)$ & 0.057 \\
\hline Junk food & $2.0(2.1)$ & $2.8(2.5)$ & $<0.001$ \\
\hline Sauces & $0.7(0.8)$ & $0.9(0.8)$ & 0.075 \\
\hline Canned foods & $1.1(1)$ & $1.2(1.3)$ & 0.158 \\
\hline Nuts and seeds & $0.6(0.8)$ & $1.0(1.2)$ & 0.021 \\
\hline Other cereals & $0.3(0.3)$ & $0.2(0.1)$ & 0.163 \\
\hline Fruits & $0.5(0.5)$ & $0.3(0.2)$ & 0.129 \\
\hline Legumes & $0.1(0.1)$ & $0.04(0.1)$ & 0.526 \\
\hline Fat and oils & $0.4(0.6)$ & $0.7(0.9)$ & 0.061 \\
\hline
\end{tabular}




\begin{tabular}{|c|c|c|c|c|}
\hline \multirow[t]{2}{*}{ Indicators } & \multicolumn{2}{|c|}{ Adults } & \multicolumn{2}{|c|}{ Children and adolescents } \\
\hline & $B$ regression (SE) & $\boldsymbol{P}$ & B regression (SE) & $\mathbf{P}$ \\
\hline Age (yr) & $-0.17(0.03)$ & $<0.001$ & $0.11(0.04)$ & 0.005 \\
\hline Male sex & $0.38(0.08)$ & $<0.001$ & $0.34(0.07)$ & $<0.001$ \\
\hline Education (yr) & $-0.34(0.09)$ & 0.003 & - & - \\
\hline Paternal education (yr) & - & - & $-0.30(0.12)$ & 0.021 \\
\hline Maternal education (yr) & - & - & $-0.28(0.11)$ & 0.029 \\
\hline Smoking status & $0.14(0.06)$ & 0.031 & $-0.08(0.07)$ & 0.231 \\
\hline Total physical activity (METs min/wk) & $-0.36(0.11)$ & 0.015 & $-0.31(0.12)$ & 0.025 \\
\hline $\mathrm{BMI}\left(\mathrm{kg} / \mathrm{m}^{2}\right)$ & $0.03(0.01)$ & 0.490 & $0.03(0.17)$ & 0.875 \\
\hline $\mathrm{WC}(\mathrm{cm})$ & $0.04(0.03)$ & 0.205 & $0.07(0.06)$ & 0.291 \\
\hline
\end{tabular}

Education entered as continues variables. BMI = body mass index; $M E T s=$ metabolic equivalent of task units; $S E=$ standard error; $W C=$ waist circumference.

Thus, it can be concluded that health education, especially in women, regarding not using a salt shaker at the table and during cooking food, might be the most important strategy for salt reduction in our society. Other measures could be: to establish compliance with salt standards for all bakers; reformulation and legal limits of salt content in food products, particularly cheese, processed meat and junk food, ; to generate a healthy environment and support settings to promote a low-salt diet; restrictions on marketing of unhealthy food such as fast food, salty snacks and biscuits to children; mandatory nutritional labelling of salt; educating people to pay attention to labels; and raising consumer awareness.

Considering the inverse association of salt intake with age, educational level and physical activity, we can conclude that elderly people take care of their health more wisely, and by increasing their education level, this will result in people paying more attention to the wellbeing of themselves and their families. People who are physically active may adhere to all aspects of a healthy lifestyle. In agreement with our findings, several studies have indicated higher salt intake in young people and people of low socioeconomic status (33-34). Consistent with our findings, previous studies have reported a positive association between smoking and excessive salt intake 35 ). It is concluded that unhealthy lifestyle factors, such as smoking might induce a preference for salt intake (36).

Among the strengths of our study, we used a validated FFQ for assessment of salt intake, and randomly selected the population from a wide range of age groups including adults, children and adolescents. Hence, it was a unique study that examined the salt intake in an Iranian city. However, there were some limitations to the current study. First, our participants were selected from only 1 large city in the Central Islamic Republic of Iran. Thus, the findings cannot be generalized to the whole country. Second, FFQ is a less valid method because of the difficulty of recalling food, and investigating many food items may result in poor accuracy in estimating daily intake, which could have overestimated sodium intake. Nevertheless, this method was used by all other studies that investigated salt content of food.

\section{Conclusion}

Sodium and salt intake were more than twice the WHO-recommended level in adults, children and adolescents in Isfahan. The main sources of sodium were added salt, bread and cheese, which provided $\sim 70 \%$ of sodium intake in the both age groups. Salt intake was significantly associated with higher age, male sex, smoking, and less education and physical activity in the adult group. In the children and adolescents, salt intake was significantly related to younger age, male sex, less physical activity and paternal education level. Future national studies are warranted to assess dietary salt intake and its main sources, and then it would be crucial to implement a salt reduction strategy in the Iranian population.

\section{Acknowledgement}

This study was conducted by Isfahan Cardiovascular Research Institute, (WHO collaborating centre) and was supported by the Department of Nutrition, the Iranian Ministry of Health and Medical Education.

\section{Funding: None.}

Competing interests: None declared.

\section{References}

1. Aaron KJ, Sanders PW. Role of dietary salt and potassium intake in cardiovascular health and disease: a review of the evidence. Mayo Clin Proc. 2013 Sep;88(9):987-95. http://dx.doi.org/10.1016/j.mayocp.2013.06.005 PMID:24001491

2. Mozaffarian D, Fahimi S, Singh GM, Micha R, Khatibzadeh S, Engell RE, et al; Global Burden of Diseases Nutrition and Chronic Diseases Expert Group. Global sodium consumption and death from cardiovascular causes. N Engl J Med. 2014 Aug 14;371(7):624-34. http://dx.doi.org/10.1056/NEJMoa1304127 PMID:25119608 


\section{Apport en sel et ses sources chez les enfants, les adolescents et les adultes à Ispahan (République islamique d'Iran) \\ Résumé}

Contexte : Il existe peu de données sur l'apport en sel et ses sources alimentaires dans la population iranienne, en particulier chez les enfants et les adolescents.

Objectifs : Étudier l'apport en sel et les sources alimentaires à Ispahan (République islamique d'Iran).

Méthodes : Il s'agissait d'une enquête transversale réalisée au cours de la période comprise entre 2014 et 2015. Nous avons sélectionné de façon aléatoire 1384 adultes âgés de plus de 18 ans (50,3\% de femmes, 49,7 \% d'hommes) [moyenne 37,9 ans (ET 10,6)] et 786 enfants et adolescents âgés de 6 à 18 ans (50,9 \% de garçons, 49,1 \% de filles) [moyenne 12,5 ans (ET 3,4)]. Tous les participants ont fait l'objet d'une évaluation diététique de leur apport en sel, à l'aide d'un questionnaire validé sur la fréquence de consommation des aliments.

Résultats : L'apport total en sel était de 10,9 g/jour chez les adultes (ET 3,4) et de 10,3 g/jour chez les enfants et les adolescents (ET 2,9). Le sel ajouté était la principale source d'apport en sel, suivi du pain et du fromage dans les deux groupes. Une relation significative a été établie entre l'apport en sel et un âge plus jeune, l'appartenance au sexe masculin, le fait de fumer, d'être moins instruit et d'être physiquement actif dans le groupe des adultes. Chez les enfants et les adolescents, il était significativement associé à un âge plus avancé, au sexe masculin, à une faible activité physique et au niveau d'éducation des parents (tous confondus, $p<0,05$ ).

Conclusions : L'apport en sel à Ispahan était plus de deux fois supérieur à celui recommandé par l'Organisation mondiale de la Santé. La principale source de sodium était le sel ajouté, suivi du pain et du fromage. De futures études nationales sont nécessaires pour évaluer l'apport en sel alimentaire et ses principales sources dans différentes provinces de la République islamique d'Iran.

$$
\begin{aligned}
& \text { مدخول الملح و مصادره لدى الأطفال والمر اهقين والبالغين في أصفهان بجمهورية إيران الإسالامية } \\
& \text { نوشين محمدفارد، أتينا مهداوي، علي رضا خسروي، أحمد إسماعيل زاده، عوض فيزي، نضال صرافزاديجان } \\
& \text { الخالاصة } \\
& \text { الخلفية: لا توجد أدلة كثيرة حول كمية مدخول الملح ومصادره الغذائية بين الإيرانيين، لا سيا الأطفال و المراهقين. } \\
& \text { الأهداف: هدفت هذه الدراسة إلى التحري عن كمية مدخول الملح ومصادره الغذائية في أصفهان بجمهورية إيران الإسلامية. }
\end{aligned}
$$

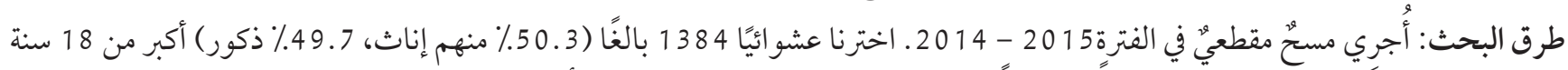

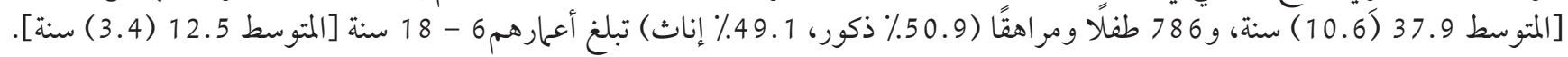

$$
\text { وخضع جميع المشار كين لتقييم غذائي لمدخول الملحج، باستبيان تواتر الغذاء وهو استبيان مصادق عليه. }
$$

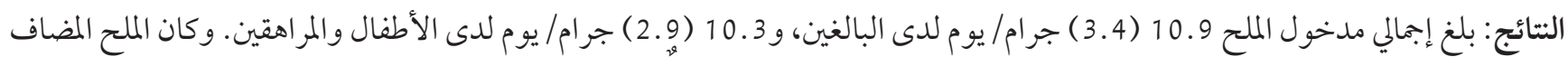

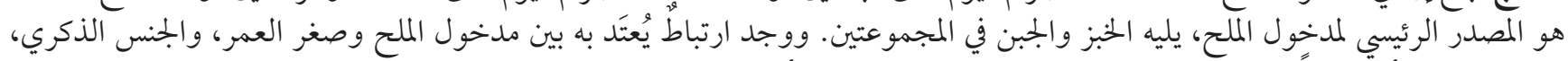

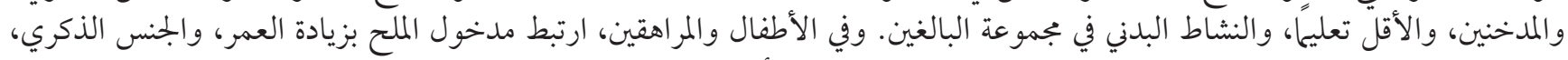

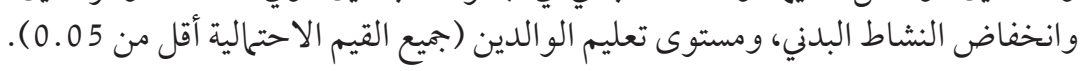

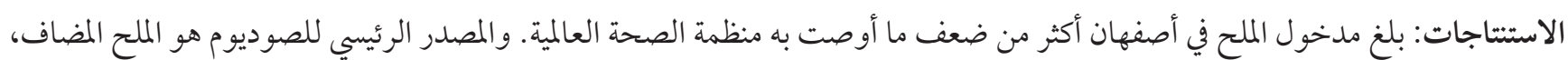

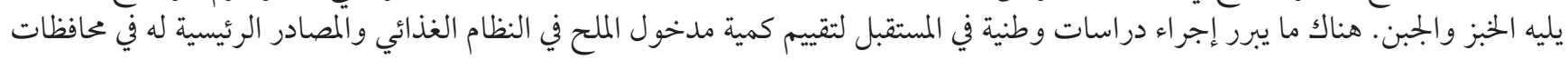
مختلفة في جمهورية إيران الإسلامية. هنب ماك

3. Mohammadifard N, Fahimi S, Khosravi A, Pouraram H, Sajedinejad S, Pharoah P, et al. Advocacy strategies and action plans for reducing salt intake in Iran. Arch Iran Med. 2012 May;15(5):320-4. PMID:22519384

4. Graudal N, Jurgens G. Conflicting evidence on health effects associated with salt reduction calls for a redesign of the salt dietary guidelines. Prog Cardiovasc Dis. 2018 May-Jun;61(1):20-6. http://dx.doi.org/10.1016/j.pcad.2018.04.008 PMID:29727609

5. Fulgoni VL, 3rd, Agarwal S, Spence L, Spence L, Samuel P. Sodium intake in US ethnic subgroups and potential impact of a new sodium reduction technology: NHANES Dietary Modeling. Nutr J. 2014 Dec 18;13(1):120. http://dx.doi.org/10.1186/1475-2891-13-120 PMID:25522786

6. Mohammadifard N, Khosravi A, Salas-Salvadó J, Becerra-Tomás N, Nouri F, Abdollahi Z, et al. Trend of salt intake measured by 24-hour urine collection samples among Iranian adults population between 1998 and 2013: The Isfahan Salt Study. Nutr Metab Cardiovasc Dis. 2019 Dec;29(12):1323-9. http://dx.doi.org/10.1016/j.numecd.2019.07.019 PMID:31672449 
7. Xu J, Wang M, Chen Y, Zhen B, Li J, Luan W, et al. Estimation of salt intake by 24-hour urinary sodium excretion: a cross-sectional study in Yantai, China. BMC Public Health. 2014 Feb 8;14:136. http://dx.doi.org/10.1186/1471-2458-14-136 PMID:24507470

8. Anderson CA, Appel LJ, Okuda N, Brown IJ, Chan Q, Zhao L, et al. Dietary sources of sodium in China, Japan, the United Kingdom, and the United States, women and men aged 40 to 59 years: the INTERMAP study. J Am Diet Assoc. 2010 May;110(5):73645. http://dx.doi.org/10.1016/j.jada.2010.02.007 PMID:20430135

9. Ponzo V, Ganzit GP, Soldati L, De Carli L, Fanzola I, Maiandi M, et al. Blood pressure and sodium intake from snacks in adolescents. Eur J Clin Nutr. 2015 Jun;69(6):681-6. http://dx.doi.org/10.1056/NEJMoa1304127 PMID:25669316

10. Toda A, Ishizaka Y, Tani M, Yamakado M. Current dietary salt intake of Japanese individuals assessed during health check-up. Hypertens Res. 2015 Feb;38(2):163-8. http://dx.doi.org/10.1038/hr.2014.154 PMID:25354779

11. Du S, Batis C, Wang H, Zhang B, Zhang J, Popkin BM. Understanding the patterns and trends of sodium intake, potassium intake, and sodium to potassium ratio and their effect on hypertension in China. Am J Clin Nutr. 2014 Feb;99(2):334-43. http:// dx.doi.org/10.3945/ajcn.113.059121 PMID:24257724

12. Mohammadifard N, Khaledifar A, Khosravi A, Nouri F, Pourmoghadas A, Feizi A, et al. Dietary sodium and potassium intake and their association with blood pressure in a non-hypertensive Iranian adult population: Isfahan salt study. Nutr Diet. 2017 Jul;74(3):275-82. http://dx.doi.org/10.1111/1747-0080.12304 PMID:28731609

13. Craig CL, Marshall AL, Sjostrom M, Bauman AE, Booth ML, Ainsworth BE, et al. International physical activity questionnaire: 12-country reliability and validity. Med Sci Sports Exerc. 2003 Aug;35(8):1381-95 PMID:12900694

14. The practical guide identification, evaluation and treatment of overweigh and obesity in adults. Bethesda, MD: National Institute of Health; 2000 (NIH Publication Number 00-4084, https://www.nhlbi.nih.gov/files/docs/guidelines/prctgd_c.pdf, accessed 30 November 2020).

15. Mohammadifard N, Khosravi AR, Esmaillzadeh A, et al. Validation of simplified tools for assessment of sodium intake in Iranian population: rationale, design and initial findings. Arch Iran Med. 2016 Sep;19(9):652-8. PMID:27631181

16. Azar M, Sarkisian E. Food Composition Table of Iran. Tehran: National Nutrition and Food Research Institute; 1980.

17. Rafiei M, Boshtam M, Marandi A, Jalali A, Vakili R. The Iranian Food Consumption Program (IFCP), a unique nutritional software in Iran. Iran J Public Health. 2002;31(3-4):105-7.

18. Mirzaei M, Moayedallaie S, Jabbari L, Mohammadi M. Prevalence of hypertension in Iran 1980-2012: a systematic review. J Tehran Heart Cent. 2016 Oct;11(4):159-67. PMID:28496506

19. Johner SA, Thamm M, Schmitz R, Rimer T. Current daily salt intake in Germany: biomarker-based analysis of the representative DEGS study. Eur J Nutr. 2015 Oct;54(7):1109-15. http://dx.doi.org/10.1007/s00394-014-0787-8 PMID:25341396

20. Vandevijvere S, De Keyzer W, Chapelle JP, Jeanne D, Mouillet G, Huybrechts I, et al. Estimate of total salt intake in two regions of Belgium through analysis of sodium in 24-h urine samples. Eur J Clin Nutr. 2010 Nov;64(11):1260-5. http://dx.doi.org/10.1038/ ejcn.2010.148 PMID:20717132

21. Maseko MJ, Majane HO, Milne J, Norton GR, Woodiwiss AJ. Salt intake in an urban, developing South African community. Cardiovasc J S Afr. 2006 Jul-Aug;17(4):186-91. PMID:17001421

22. Froment A, Milon H, Gravier C. [Relationship of sodium intake and arterial hypertension. Contribution of geographical epidemiology (author's transl)]. Rev Epidemiol Sante Publique. 1979;27(5-6):437-54 (in French). PMID:554290

23. Batcagan-Abueg AP, Lee JJ, Chan P, Rebello SA, Amarra MS. Salt intakes and salt reduction initiatives in Southeast Asia: a review. Asia Pac J Clin Nutr. 2013;22(4):490-504. doi: 10.6133/apjcn.2013.22.4.04. PMID: 24231008.

24. Shao S, Hua Y, Yang Y, Liu X, Fan J, Zhang A, Xiang J, Li M, Yan LL. Salt reduction in China: a state-of-the-art review. Risk Manag Healthc Policy. 2017 Feb 22;10:17-28. doi: 10.2147/RMHP.S75918. PMID: 28260957.

25. Hasenegger V, Rust P, Konig J, Purtscher AE, Erler J, Ekmekcioglu C. Main sources, socio-demographic and anthropometric correlates of salt intake in Austria. Nutrients. 2018 Mar 6;10(3):E311. http://dx.doi.org/10.3390/nu10030311 PMID:29509671

26. Quilez J, Salas-Salvado J. Salt in bread in Europe: potential benefits of reduction. Nutr Rev. 2012 Nov;70(11):666-78. doi: 10.1111/j.1753-4887.2012.00540.x. PMID: 23110645.

27. Bhat S, Marklund M, Henry ME, Appel LJ, Croft KD, Neal B, Wu JHY. A Systematic Review of the Sources of Dietary Salt Around the World. Adv Nutr. 2020 May 1;11(3):677-686. doi: 10.1093/advances/nmz134. PMID: 31904809

28. Bolton KA, Webster J, Dunford EK, Jan S, Woodward M, Bolam B, Neal B, Trieu K, Reimers J, Armstrong S, Nowson C, Grimes C. Sources of dietary sodium and implications for a statewide salt reduction initiative in Victoria, Australia. Br J Nutr. 2020 May 28;123(10):1165-1175. doi: 10.1017/Soo0711452000032X. PMID: 31992370.

29. Rosi A, Paolella G, Biasini B, Scazzina F; SINU Working Group on Nutritional Surveillance in Adolescents. Dietary habits of adolescents living in North America, Europe or Oceania: A review on fruit, vegetable and legume consumption, sodium intake, and adherence to the Mediterranean Diet. Nutr Metab Cardiovasc Dis. 2019 Jun;29(6):544-560. doi: 10.1016/j.numecd.2019.03.003. PMID: 31078365.Keats EC, Rappaport AI, Shah S, Oh C, Jain R, Bhutta ZA. The dietary intake and practices of adolescent girls in low- and middle-income countries: a systematic review. Nutrients. 2018;10(12):1978. http://dx.doi.org/10.3390/nu10121978 PMID:30558128

30. Keats EC, Rappaport AI, Shah S, Oh C, Jain R, Bhutta ZA. The dietary intake and practices of adolescent girls in low- and middle-income countries: a systematic review. Nutrients. 2018;10(12):1978. http://dx.doi.org/10.3390/nu10121978 PMID:30558128 
31. Fidler Mis N, Kobe H, Stimec M. Dietary intake of macro- and micronutrients in Slovenian adolescents: comparison with reference values. Ann Nutr Metab. 2012;61(4):305-13. http://dx.doi.org/10.1159/000342469 PMID:23208160

32. Charlton KE, MacGregor E, Vorster NH, Levitt NS, Steyn K. Partial replacement of NaCl can be achieved with potassium, magnesium and calcium salts in brown bread. Int J Food Sci Nutr. 2007 Nov;58(7):508-21. doi: 10.1080/09637480701331148. PMID: 17852502 .

33. Nerbass FB, Pecoits-Filho R, McIntyre NJ, McIntyre CW, Willingham FC, Taal MW. Demographic associations of high estimated sodium intake and frequency of consumption of high-sodium foods in people with chronic kidney disease stage 3 in England. J Ren Nutr. 2014 Jul;24(4):236-42. doi: 10.1053/j.jrn.2014.03.003. PMID: 24788310.

34. de Mestral C, Mayén AL, Petrovic D, Marques-Vidal P, Bochud M, Stringhini S. Socioeconomic Determinants of Sodium Intake in Adult Populations of High-Income Countries: A Systematic Review and Meta-Analysis. Am J Public Health. 2017 Apr;107(4):e1-e12. doi: 10.2105/AJPH.2016.303629. PMID: 28207328.

35. Lampure A, Schlich P, Deglaire A, Castetbon K, Péneau S, Hercberg S, et al. Sociodemographic, psychological, and lifestyle characteristics are associated with a liking for salty and sweet tastes in French adults. J Nutr. 2015 Mar;145(3):587-94. http://dx.doi. org/10.3945/jn.114.201269 PMID:25733476

36. Choi K-H, Park M-S, Kim JA, Lim JA. Associations between excessive sodium intake and smoking and alcohol intake among Korean men: KNHANES V. Int J Environ Res Public Health. 2015 Dec 8;12(12):15540-9. http://dx.doi.org/10.339o/ijerph121215001 PMID:26670236 